\title{
ELECTROPHYSICAL PROPERTIES OF GaAs P-I-N STRUCTURES FOR CONCENTRATOR SOLAR CELL APPLICATIONS
}

\author{
Arpád Kósa * - Miroslav Mikolášek * L'ubica Stuchlíková * \\ Ladislav Harmatha * - Wojciech Dawidowski ${ }^{* *}$ \\ Beata Ściana $^{* *}$ - Marek Tłaczała ${ }^{* *}$
}

\begin{abstract}
This paper is dedicated to electro-physical characterisation of a GaAs p-i-n structure grown for solar cell applications, which was carried out by light and dark current-voltage $(I-V)$ and Deep Level Transient Fourier Spectroscopy (DLTFS) methods. The conversion efficiency and open-circuit voltage were determined from $I-V$ measurement at 1 and $20 \times$ sun light concentrations. Three electron like defects $\mathrm{TA}_{\mathrm{n} 1}, \mathrm{TA}_{\mathrm{n} 2}, \mathrm{TD}_{\mathrm{n}}$ and one hole like defect $\mathrm{TBp}$ obtained by DLTFS measurements were confirmed. The origin of these defect states was stated as native GaAs impurities.
\end{abstract}

K e y w or d s: solar cell, GaAs concentrator solar cell, $I-V$ measurement, DLTFS, defects

\section{INTRODUCTION}

Solar energy is one of the many energy forms harnessed by humanity in order to produce electricity in an environmental friendly and efficient way. Among the various solar cell technologies [1-3], GaAs concentrator solar cells have the potential to achieve higher conversion efficiencies and are promising for space and terrestrial applications $[4,5]$. These solar cell structures are optimized for specific applications — such as satellites, photovoltaic concentrator systems and laser power beaming. The record efficiency $28.8 \%$, GaAs solar cell had achieved in 2011 [5]. Due to their good properties such as high quantum efficiency and good irradiation tolerance, they are the ideal choices for space applications $[7,8]$. In comparison with Si space solar cells, the radiation reliability of GaAs solar cells is over $20 \%$ higher and the efficiency of energy conversion is $20-25 \%$ and above. The lifetime in orbits of GaAs solar cells is $40-60 \%$ over the one of Si solar cells $[9,10]$.

Key factor of development is to understand recombination dynamics in GaAs solar cell structures. Valuable feedback for the technology process is provided by the Deep Level Transient Fourier Spectroscopy (DLTFS) method, which represents a unique technique of electrically active defect and recombination centre investigation.

The aim of this paper is to introduce and discuss results of DLTFS defect investigations of the GaAs concentrator solar cell grown by Atmospheric Pressure Metal Organic Vapour Phase Epitaxy (AP-MOVPE).

In addition, temperature dependent dark and light current voltage characteristics at two light concentrations were carried out to gain further insight on the structure operation and performance.

\section{EXPERIMENTAL}

\subsection{Device processing}

The investigated p GaAs:Zn/i GaAs/n GaAs: Si solar cell was grown by AP-MOVPE on a n-type GaAs (Si doped) substrate at the Wroclaw University of Science and Technology. The GaAs p-i-n junction was sandwiched between a $\mathrm{Si}$ doped GaAs substrate with $n=$ $1 \div 2 \times 10^{18} \mathrm{~cm}^{-3}$ and a $50 \mathrm{~nm}$ thick $\mathrm{Zn}$ doped $\mathrm{p}^{+}=$ $1 \div 3 \times 10^{19} \mathrm{~cm}^{-3}$ cap layer. GaAs $\mathrm{p}$-i-n with thicknesses of $200 / 800 / 200 \mathrm{~nm}$ was connected with the substrate by a $\mathrm{n}$ type GaAs $200 \mathrm{~nm}$ thick buffer layer with $n=2 \div 3 \times 10^{18} \mathrm{~cm}^{-3}$

Doping concentrations of the $\mathrm{p}-\mathrm{i}-\mathrm{n}$ region was as follows: p layer $p=2 \div 3 \times 10^{18} \mathrm{~cm}^{-3}$ and $n$ layer as a gradient $n=2 \div 3 \times 10^{18} \mathrm{~cm}^{-3}$ to $n=1 \div 2 \times 10^{17} \mathrm{~cm}^{-3}$, Fig. 1.

\begin{tabular}{|l|c|c|}
\hline Type & Thickness & $n, p\left(\mathrm{~cm}^{-3}\right)$ \\
\hline p GaAs cap:Zn & $\sim 50 \mathrm{~nm}$ & $1 \div 3 \times 10^{18}$ \\
\hline p GaAS:Zn & $\sim 200 \mathrm{~nm}$ & $2 \div 3 \times 10^{18}$ \\
\hline i GaAS & $\sim 200 \mathrm{~nm}$ & - \\
\hline n GaAs:Si & $\sim 800 \mathrm{~nm}$ & $\begin{array}{c}\text { gradient } 1 \div 2 \times 10^{17} \\
\text { to } 2 \div 3 \times 10^{18}\end{array}$ \\
\hline n+ GaAs:Si buffer & $\sim 200 \mathrm{~nm}$ & $2 \div 3 \times 10^{18}$ \\
\hline n GaAs:Si substrate & $\sim 350 \mathrm{~nm}$ & $2 \div 3 \times 10^{18}$ \\
\hline
\end{tabular}

Fig. 1. Material compositions and layer properties of the investigated p-i-n sample

\footnotetext{
* Slovak University of Technology, Faculty of Electrical Engineering and Information Technology, Institute of Electronics and Photonics, Ilkovičova 3, 81219 Bratislava, Slovakia, lubica.stuchlikova@stuba.sk; ${ }^{* *}$ Wrocław University of Science and Technology, Faculty of Microsystem Electronics and Photonics, Janiszewskiego 11/17, 50-372, Wrocław, Poland, marek.tlaczala@pwr.edu.pl
} 


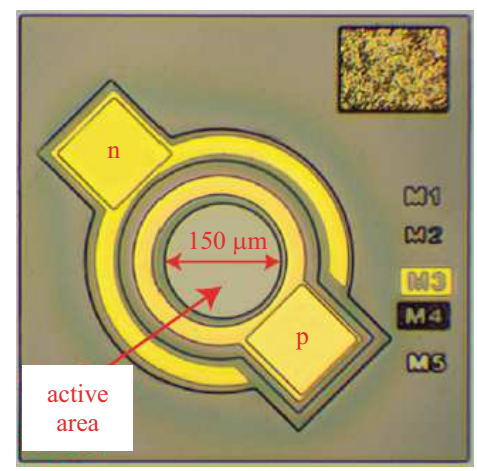

Fig. 2. Image of the fabricated metallization of test solar cell structure - typical detector configuration with the circle shape active area

The metallization was prepared as a typical detector ring structure with an inner diameter $150 \mu \mathrm{m}$ (circle shaped active area), where the metallic p-type

$(\mathrm{Pt} / \mathrm{Ti} / \mathrm{Pt} / \mathrm{Au})$ and $\mathrm{n}$-type $(\mathrm{AuGe} / \mathrm{Ni} / \mathrm{Au})$ contacts were deposited under vacuum conditions on the top and around the mesa, respectively, Fig. 2.

\subsection{Experiment}

Fabricated GaAs p-i-n solar structure was investigated by current-voltage $(I-V)$ and DLTFS measurements [11]. Light and dark $I-V$ measurements were carried out using a source-meter unit Keithley $2612 \mathrm{~A}$ in temperature range from $100 \mathrm{~K}$ to $400 \mathrm{~K}$. Solar simulator 16S-002-300 with spectrum AM1.5 was used as a source of illumination. The nitrogen cryostat system with quartz glass window was used for temperature control during the measurements. The optical loses due to the glass window are around $10 \%$. The light $I-V$ measurements were carried out under $1 \times$ sun light intensity $\left(100 \mathrm{~mW} / \mathrm{cm}^{2}\right)$ and under $20 \times$ sun light intensity $\left(2000 \mathrm{~mW} / \mathrm{cm}^{2}\right)$ achieved by focusing the light with Fresnel lens.

Electrically active defects (deep energy levels) were investigated by the DLTFS BIORAD DL8000 measuring system in temperature range from $85 \mathrm{~K}$ to $550 \mathrm{~K}$. Measured capacitance transients were evaluated by Fourier transform analysis. This method is based on measurements of capacitance differences caused by excited emission and capture processes of deep energy levels in semiconductor materials [12]. The obtained DLTFS spectra were evaluated using the Fourier transform analysis by "Direct auto Arrhenius single level evaluation". The values of activation energies $\Delta E_{T}$ and cross sections $\sigma_{T}$ of deep energy levels were determined from an Arrhenius diagram using known equations $[11,12]$.

\section{RESULTS AND DISCUSSION}

Figures 3(a)-(c) show temperature dependent $I-V$ characteristics of the investigated GaAs p-i-n structure measured in the dark and under sun simulator with $1 \times$ sun and $20 \times$ sunlight concentrations.
Light $I-V$ measurements allowed us to determine basic output photovoltaic parameters: open circuit voltage $V_{\mathrm{OC}}$, short circuit current density $J_{\mathrm{SC}}$, fill factor $F F$, and conversion efficiency $\eta_{f}$, which are summarized for $T=300 \mathrm{~K}$ in Tab. 1 . Temperature dependent output parameters for $1 \times$ sun and $20 \times$ sun light concentration are shown in Figs. 4(a)-(d).

Table 1. Solar cell output parameters extracted from light $I-V$ characteristics of the GaAs p-i-n structure at $T=300 \mathrm{~K}$

\begin{tabular}{ccccccc}
\hline $\begin{array}{c}V_{\mathrm{oc}} \\
(\mathrm{V})\end{array}$ & $\begin{array}{c}J_{\mathrm{sc}} \\
\left(\mathrm{A} / \mathrm{cm}^{2}\right)\end{array}$ & $\begin{array}{c}V_{\max } \\
(\mathrm{V})\end{array}$ & $\begin{array}{c}J_{\max } \\
\left(\mathrm{A} / \mathrm{cm}^{2}\right)\end{array}$ & $\begin{array}{c}F F \\
(\%)\end{array}$ & $\begin{array}{c}\eta_{\mathrm{f}} \\
(\%)\end{array}$ & Intensity \\
\hline 0.74 & 0.02 & 0.62 & 0.015 & 74.7 & 9.09 & $1 \times$ sun \\
0.87 & 0.35 & 0.73 & 0.323 & 76.6 & 11.70 & $20 \times$ sun \\
\hline
\end{tabular}

Figure 4(a) shows a negligible change of $J_{\mathrm{SC}}$ with $T$ for both $1 \times$ sun and $20 \times$ sun light concentrations. More significant temperature dependencies are observed for $V_{\mathrm{OC}}, F F$ which are consequently reflected also in $\eta_{\mathrm{f}}$, Fig. 4(b)-(d). The decrease of the $V_{\mathrm{OC}}$ upon the temperature has a physical origin and it can be explained by considering the following equation

$$
V_{\mathrm{OC}}=\frac{A k T}{q} \ln \frac{J_{\mathrm{SC}}}{J_{\mathrm{Sat}}},
$$

where $A$ is the ideality factor, $J_{\text {Sat }}$ is the saturation current density and $J_{\mathrm{SC}}$ is the short-circuit current density. $J_{\text {Sat }}$ is strongly related with intrinsic carrier concentration of the GaAs, which increases upon the increase of temperature resulting into the increase of $J_{\text {Sat }}$. While the $V_{\mathrm{OC}}$ is reciprocally proportional to the saturation current, the $V_{\mathrm{OC}}$ increases with the decrease of $T$, Fig. 4(b).

Both $V_{\mathrm{OC}}$ and $F F$ have downward trends with the $T$ and determine the temperature behaviour of $\eta_{\mathrm{f}}$. The temperature dependent $\eta_{\mathrm{f}}$ allowed us to determine temperature coefficients of efficiency $\eta_{\mathrm{TKR}}$ (in the linear temperature region $200-400 \mathrm{~K}$ ) with values of -0.37 and $-0.31 \% /{ }^{\circ} \mathrm{C}$ for light concentrations $1 \times$ sun and $20 \times$ sun, respectively. Such a coefficient describes the relative decrease of the efficiency with the increase of $T$.

Considering (1) it is obvious that high $J_{\text {sat }}$ has a detrimental effect on the $V_{\mathrm{OC}}$ and thus on the output photovoltaic performance. High quality materials with low concentration of defects are required to keep the $J_{\text {sat }}$ low. The investigation of electrically active recombination centres is therefore crucial for optimization of solar cells. Using the DLTFS method, four deep energy levels were detected (Figs. 5, 6) in the investigated structure. Three of them, labelled by us as $\mathrm{TA}_{\mathrm{n} 1,2}$, and $\mathrm{TD}_{\mathrm{n}}$, are linked to majority traps and one labelled as $\mathrm{TB}_{\mathrm{p}}$ to a minority trap. We have produced several DLTFS spectra sets by experiments with different initial measurement conditions filling $\left(U_{P}\right)$ and reverse $\left(U_{R}\right)$ voltages, capacitance transient period width - time period $\left(T_{w}\right)$ and filling pulse length $\left(t_{P}\right)$. Typical DLTFS spectra measured on the GaAs p-i-n solar structure are displayed in Fig. 5. 

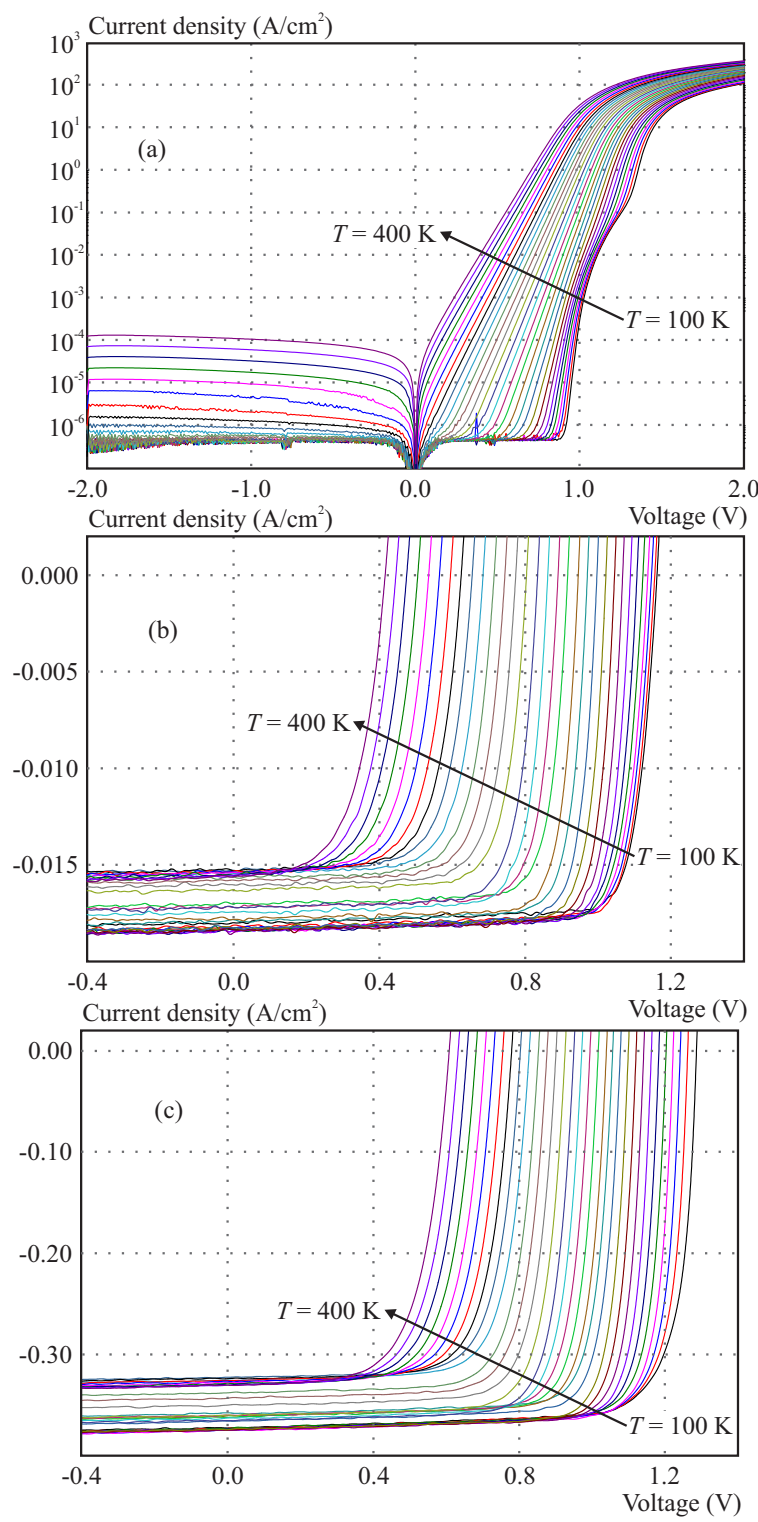

Fig. 3. Temperature dependent current-voltage characteristics of the GaAs p-i-n structure measured in the dark (a) - and under solar simulator with (b) $-1 \times$ sun, and (c) $-20 \times$ sun concentrated light

Table 2. Calculated and compared deep energy level parameters of $\mathrm{TA}_{\mathrm{n} 1}, \mathrm{TA}_{\mathrm{n} 2}$ and $\mathrm{TB}_{\mathrm{p}}$ before and after data selection with various evaluation procedures

\begin{tabular}{|c|c|c|c|c|c|}
\hline Trap & $\begin{array}{l}\Delta E_{\mathrm{T}} \\
(\mathrm{eV})\end{array}$ & $\sigma_{\mathrm{T}}\left(\mathrm{cm}^{2}\right)$ & $\begin{array}{c}\Delta E_{\text {Tref }} \\
(\mathrm{eV})\end{array}$ & 2) & Origin \\
\hline $\mathrm{TA}_{\mathrm{n} 1}$ & 0.486 & & $\begin{array}{l}0.48 \mathrm{eV} \\
\mathrm{EC} 2\end{array}$ & & \\
\hline $\mathrm{TA}_{\mathrm{n} 2}$ & 400 & & $\begin{array}{l}0.37 \mathrm{eV} \\
\text { EL16 }\end{array}$ & & 3] \\
\hline $\mathrm{TH}$ & 0.691 & 2.04 & $\begin{array}{c}0.63 \mathrm{eV} \\
\mathrm{HC} 1\end{array}$ & 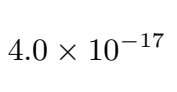 & $\begin{array}{c}\mathrm{Zn} / \mathrm{Ni} \\
{[12]}\end{array}$ \\
\hline $\mathrm{TD}_{\mathrm{n}}$ & 0.747 & $2.95 \times 10^{-15}$ & $\begin{array}{c}0.73 \mathrm{eV} \\
\text { EX2 }\end{array}$ & $1.3 \times 10^{-14}$ & $\begin{array}{l}\text { AsGa } \\
{[15]}\end{array}$ \\
\hline
\end{tabular}

The reverse and filling voltage variation allowed us to estimate the type and layer origin of these specific responses. Since in the case of a p-i-n structure the depletion region is located at the i-layer, the active layer of the solar cell, the presence of these defect states can greatly affect the efficiency.

Figure 4(b) shows higher $V_{\mathrm{OC}}$ for $20 \times$ sun compared to $1 \times$ sun light concentration. This phenomenon could be explained by considering (1). While the $J_{\text {Sat }}$ is not dependent on light, the $V_{\mathrm{OC}}$ increases with the increase of $J_{\mathrm{SC}}$ at the higher light concentration.

The $F F$ exhibits initial increase upon the decrease of $T$, which is followed by saturation in the temperature region of $200-100 \mathrm{~K}$. The $F F$ is a very complex parameter, which describes the current transport, recombination of carriers and contact properties in the structure.

At slightly forward biased conditions hole injection to the $\mathrm{i}$ layer is ensured thereby the DLTFS curve should include also results from minority carrier traps. Higher filling voltages should increase the injection thereby amplifying initial or reveal additional minority traps. This procedure is visible in Fig. 5(a), where in the first case at higher $U_{\mathrm{P}}$ value $(0.3 \mathrm{~V})$ the minority trap $\mathrm{TB}_{\mathrm{p}}$ indicated increasing tendencies, while in the second at a very low value of reverse voltage $U_{\mathrm{R}}=-2 \mathrm{~V}$ the minority response disappeared revealing an additional majority trap $\mathrm{TD}_{\mathrm{n}}$, Fig. 5(b). Figure 6 shows the obtained Arrhenius curves where $\mathrm{TA}_{\mathrm{n} 1,2}$ and $\mathrm{TB}_{\mathrm{p}}$ were calculated at $U_{R}=-0.1 \mathrm{~V} U_{P}=0.3 \mathrm{~V} T_{W}=0.3,1,3 \mathrm{~ms}$ and $t_{P}=$ $0.3 \mathrm{~ms}$, while $\mathrm{TD}_{\mathrm{n}}$ was identified at $U_{\mathrm{R}}=-2 \mathrm{~V}, U_{\mathrm{P}}=$ $0.05 \mathrm{~V}, T_{\mathrm{W}}=2.5 \mathrm{~s}$ and $t_{\mathrm{P}}=0.8 \mathrm{~ms}$. At $U_{\mathrm{R}}=-0.1 \mathrm{~V}$, $U_{\mathrm{P}}=0.3 \mathrm{~V}$ not only the peak amplitude of $\mathrm{TB}_{\mathrm{p}}$ but also $\mathrm{TA}_{\mathrm{n} 1,2}$ was increased. This fact indicated that one of the $\mathrm{TA}_{\mathrm{n} 1,2}$ complex (EC2 or EL16) has a more significant concentration at the $\mathrm{i} / \mathrm{n}$ interface. Also higher hole injection $\left(U_{\mathrm{P}}=0.3 \mathrm{~V}\right.$, increased peak of $\left.\mathrm{TB}_{\mathrm{p}}\right)$ made possible to more precisely detect the $\mathrm{TB}_{\mathrm{p}}$ level. $\mathrm{TD}_{\mathrm{n}}$ was identified as EL2 (EX2) a frequently described and discussed arsenic antisite defect of GaAs, by lowering the reverse voltage to $-2 \mathrm{~V}$.

At these measurement parameters of the $\mathrm{TA}_{n 1,2}$ level was also evidently present, but unfortunately it was no separable by the deconvolution method, Fig. 5(b). Only the presence of $\mathrm{TA}_{\mathrm{n} 1}$ was confirmed more strongly suggesting that $\mathrm{TA}_{\mathrm{n} 2}$ is located near the $\mathrm{i} / \mathrm{n}$ interface.

Table 2 lists the evaluated deep energy levels with their parameters (activation energy $\Delta E_{\mathrm{T}}$, capture crosssection $\sigma_{\mathrm{T}}$ ) and the probable origin of the deep energy level. All energy levels that were evaluated were identified as well-known material defects of GaAs. Electron energy level $\mathrm{TA}_{\mathrm{n} 1}$ was identified as $\mathrm{EC} 2(0.48 \mathrm{eV}$, $\left.3.8 \times 10^{-16} \mathrm{~cm}^{2}\right)$ and was originated from a $\mathrm{Ni}_{\mathrm{Ga}}$ complex [13]. It is highly probable that this defect state was introduced by the growth process. The second electron energy level $\mathrm{TA}_{\mathrm{n} 2}$ was identified as EL16 $(0.375 \mathrm{eV}$, $\left.4.0 \times 10^{-18} \mathrm{~cm}^{2}\right)[14]$. Not many reports were published about this defect state, therefore the possible origin of a complex defect state between EC2 and EL16 is thereby not clearly understood. In our interpretation the $\mathrm{TA}_{\mathrm{n}, 2}$ level (EL16) could be introduced by the GaAsi-n interface of the GaAs p-i-n sample, which together with the 

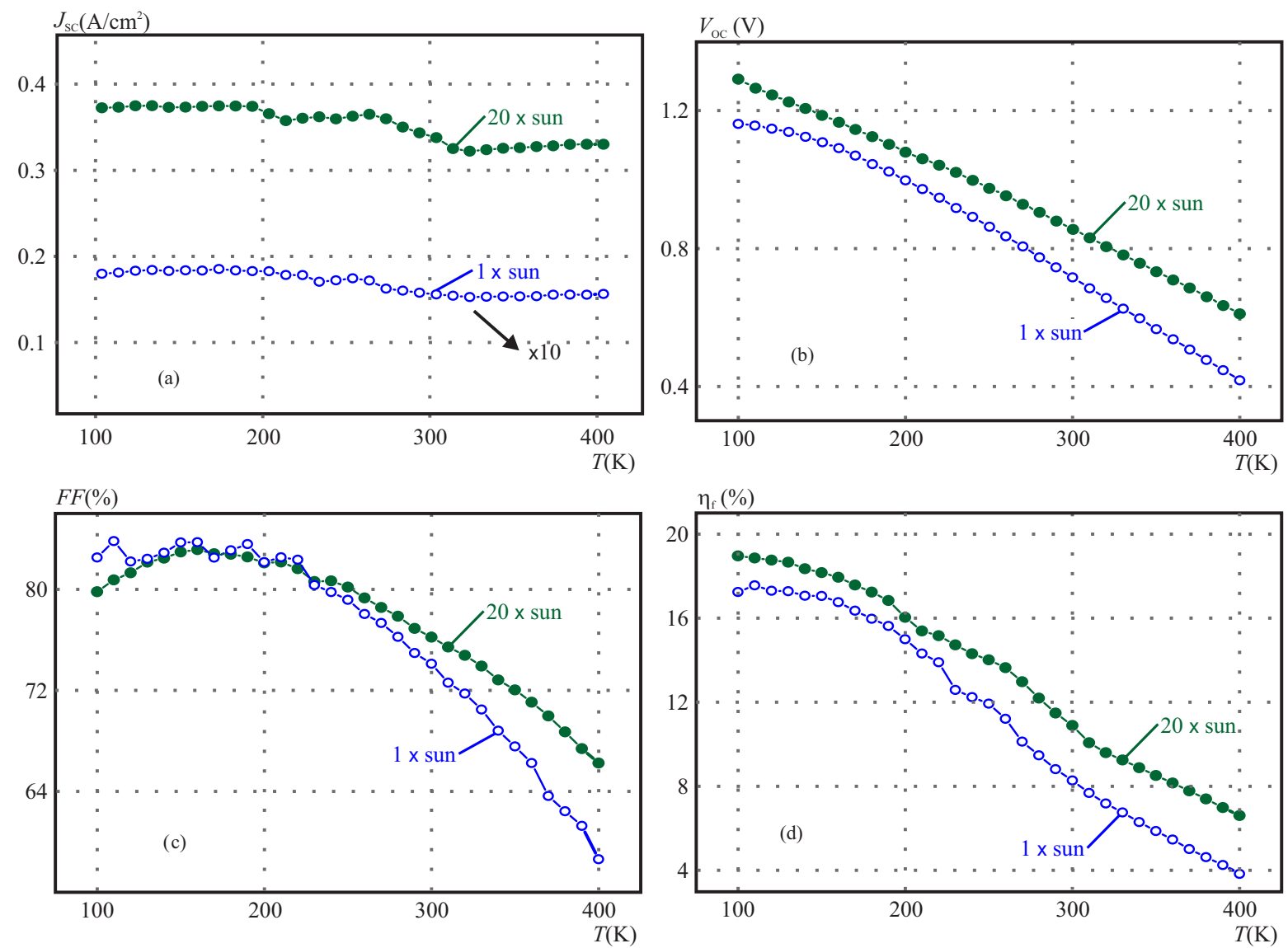

Fig. 4. Extracted (a) $-J_{\mathrm{SC}}$, (b) $-V_{\mathrm{OC}},(\mathrm{c})-F F$, and $(\mathrm{d})-\eta_{f}$ as a function of temperature at $1 \times$ sun and $20 \times$ sun light concentration

EC2 response produces a complex DLTFS peak in the spectrum.
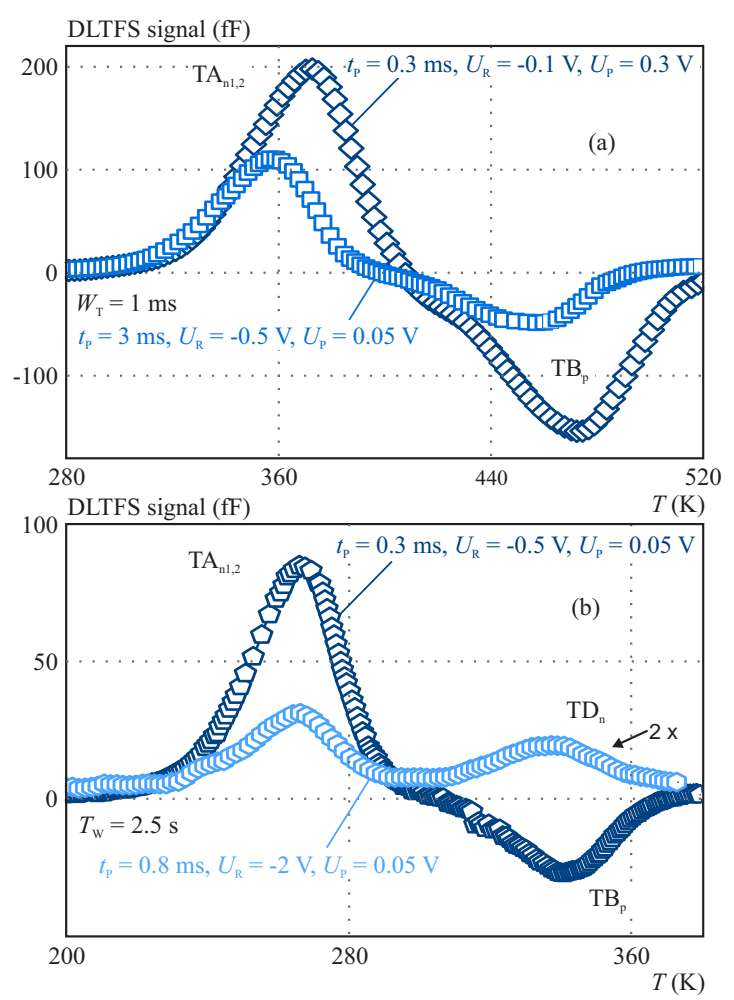

Fig. 5. DLTFS measurements of the GaAs p-i-n sample at different reverse $\left(U_{\mathrm{R}}\right)$ and filling voltage $\left(U_{\mathrm{P}}\right)$ conditions
Our investigation showed, that the deep energy level $\mathrm{TB}_{\mathrm{p}}$ highly corresponds with a single $\mathrm{p}$ type deep energy level $\mathrm{HC} 1\left(0.63 \mathrm{eV}, 4.0 \times 10^{-17} \mathrm{~cm}^{2}\right)$. According to the literature $\mathrm{HC} 1$ was observed in VPE samples diffused with $\mathrm{Zn}$ (Ni, Zn), which were used to study hole traps [13]. $\mathrm{Zn}$ creates a shallow p type donor level at $0.024 \mathrm{eV}$ so it was ruled out.

Definite origin of HC1 was not stated however a minority character trap caused by majority carrier capture (electron) was described. A further example of this energy state showed a hole trap population including the energy $0.63 \mathrm{eV}$ where oxygen was also discussed possibly accommodating certain charge states [15]. Presence of oxygen in MOVPE grown samples are frequently observed, therefore we can not entirely rule out this consideration. The electron trap $\mathrm{TD}_{\mathrm{n}}$ probably corresponds with defects EX2 or EL2. EL2 is a mid-gap defect level of GaAs, more precisely an arsenic antisite defect. EX2 is a formation of EL2 identified in annealed GaAs samples by rapid thermal annealing process [16].

It was suggested that EX2 is a complex of two vacancies and an antisite without interstitial arsenic atoms $\left(\mathrm{V}_{\mathrm{As}}, \mathrm{V}_{\mathrm{Ga}}, \mathrm{As}_{\mathrm{Ga}}\right)$. To ensure a more pure growth process further investigations are needed in connection with all possible relations of the observed defects and the growth technology. 

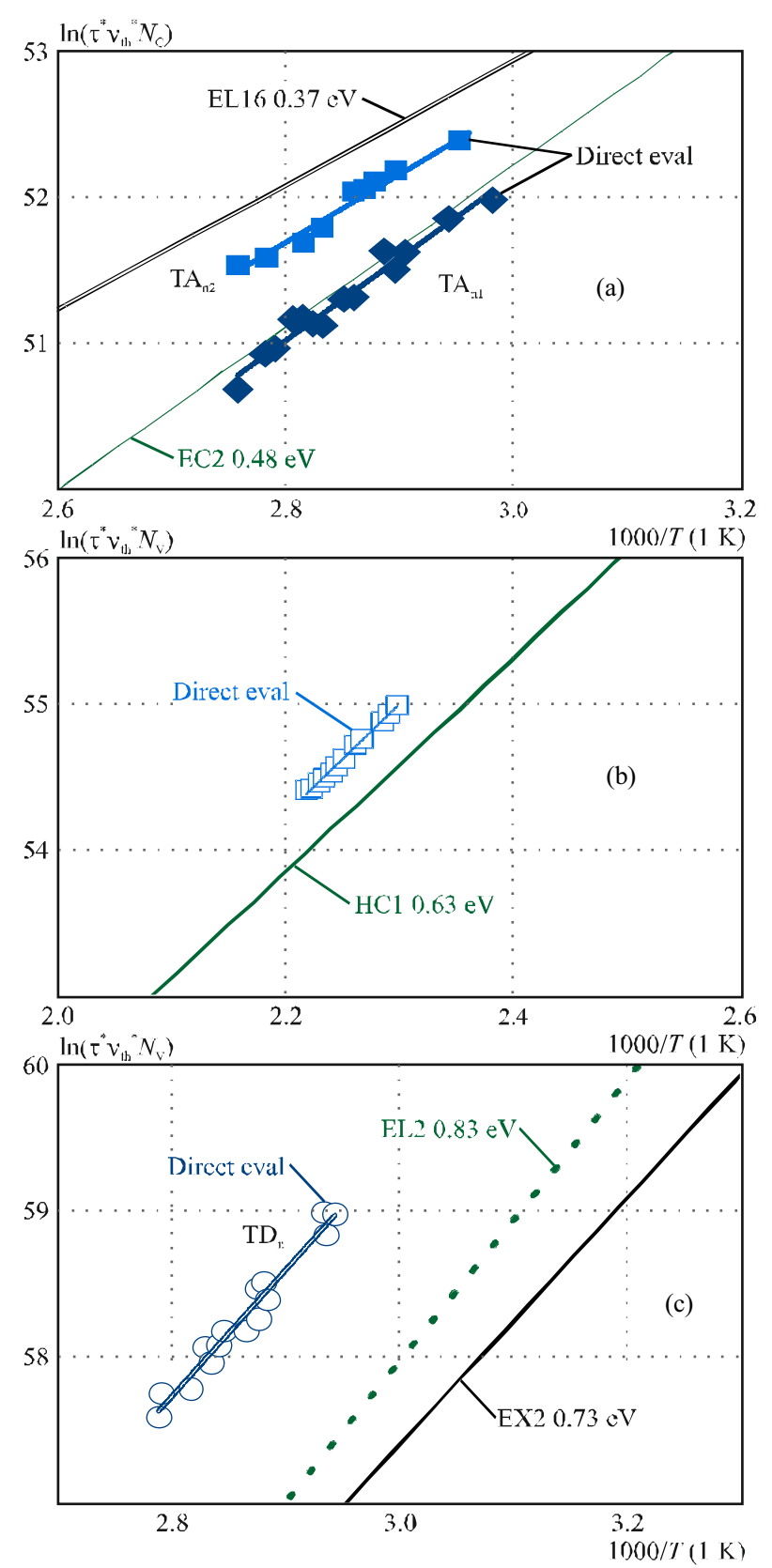

Fig. 6. Arrhenius curves of the GaAs p-i-n sample after DLTFS parameter variations. Arrhenius curves (a) - of the complex defect state $\mathrm{TA}_{\mathrm{n} 1,2}$ with defined reference data (EC2+EL16), (b) - of the defect state $\mathrm{TB}_{\mathrm{p}}$ with reference data $\mathrm{HC} 1$, (c) - of the defect state $\mathrm{TD}_{\mathrm{n}}$ with reference data EL2 and EX2

\section{CONCLUSION}

This paper summarises the results of temperature dependent light and dark $I-V$ measurements and DLTFS study of a GaAs p-i-n solar cell structure. Comparing output performance at different light conditions, the higher conversion efficiency as well as better temperature coefficient of efficiency measured at $20 \times$ sun light intensity indicated a good applicability of developed structures for concentrator applications. Four electrically active defects were confirmed by means of DLTFS. These were identified with high probability in connection with the growth pro- cess as well-known material defects of GaAs originated from a $\mathrm{Ni}_{\mathrm{Ga}}$ complex, Oxygen and the arsenic antisite defect EL2. To achieve an increased efficiency, improved GaAs quality and the optimization of the solar cell design decreased concentration of recombination centres are needed.

\section{Acknowledgment}

This work has been supported by the Scientific Grant Agency of the Ministry of Education of the Slovak Republic (Project VEGA 1/0651/16) and by Wroclaw University of Science and Technology statutory grants. This contribution is also the result of the project implementation of the National Centre for Research and Application of Renewable Energy Sources (ITMS: 26240120016), supported by the Research \& Development Operational Programme funded by the EU.

\section{REFERENCES}

[1] ZEMAN, M.: Thin-Film Silicon PV Technology, Journal of Electrical Engineering 61 No. 5 (2010), 271-276.

[2] MIKOLÁŠEK, M.-JAKABOVIŠ, J.— ŘEHÁČEK, V.-HARMATHA, L.-ANDOK, R. : Capacitance Analysis of the Structures with the a-Si: H (i)/c-Si (p) Heterojunction for Solar-Cell Applications, Journal of Electrical Engineering 65 No. 4 (2014), 254-258.

[3] HARMATHA, L.-MIKOLÁŠEK, M.-KÓSA, A.-ŽIŠKA, M.-HRUBČÍN, L.-SKURATOV, V. A.: Electrically Active Defects in Solar Cells Based on Amorphous Silicon/Crystalline Silicon Heterojunction after Irradiation by Heavy Xe Ions, Journal of Electrical Engineering 66 No. 6 (2015), 323-328.

[4] TAKA, N.-KURAKATA, H.-OKUNO, T.-YOSHIDA, S.MAtsugoto, H.-GOTO, M. et al: Space Proven GaAs Solar Cells-Main Power Generation for CS-3, IEEE, 1219-24 1990.

[5] PERnÝ, M.-KUSKO, M.-ŠÁLY, V.-PACKA, J. : PV Concentrator Cells Complex Impedance under the Bias in the Dark, Conference Record of the IEEE Photovoltaic Specialists Conference, art. no. 5614438, 2010, pp. 1461-1464.

[6] GREEN, M, A.-EMERY, K.-HISHIKAWA, Y.-WARTA, V.-DUNLOP, E. D. : Solar Cell Efficiency Tables (version 47), Prog. Photovolt: Res. Appl. 24 (2016), 3-11.

[7] ASIM, N.-SOPIAN, K.-AHMADI, S.-SAEEDFAR, K.ALGHOUL, M. A.-SAADATIAN, O. et al: A Review on the Role of Materials Science in Solar Cells, Renew Sustain Energy Rev 16 (2012), 5834-47.

[8] FRAAS, L.-PARTAIN, L. : Solar Cells and their Applications, 2nd ed., John Wiley \& Sons, Inc., 2010.

[9] LILENSTEN, J. : Le Systeme Solaire Revisite, Edition Eyrolles, 2006.

[10] LOO, R. Y.-KAMATH, G. S. Li,-S. S.: Radiation Damage and Annealing in GaAs Solar Cells, IEEE Trans Electron Devices 31 No. 2 (Feb 1990).

[11] WEISS, S.-KASSING, R. : Deep Level Transient Fourier Spectroscopy (DLTFS) - A Technique for the Analysis of Deep Level Properties, Solid-State Elecrronics 31, No. 12 (1988), 1733-1742, Institut für Technische Physik, Universität Kassel Dl-3500 Kassel F.R.G..

12] LANG, D. V.: Deep Level Transient Spectroscopy: A New Method to Characterize Traps in Semiconductors, J. Appl. Phys. 45 (1974), American Institute of Physics.

13] PARTIN, D. L.-CHEN, J. W.-MILNES, A. G.-VASSAMILLET, L. F.: Deep Level Transient Spectroscopy Studies of Ni 
and Zn Diffused Vapour Phase Epitaxy n GaAs, Journal of Applied Physics 50 (1979), 6845, doi: 10.1063/1.325884.

[14] ENGSTROM, O.-KANIEWSKA, M.: Discovery of Classes among Deep Level Centers in Gallium Arsenide, Materials Science and Engineering: B 138.1 (2007), 12-15.

[15] DONEKER, J.-RECHENBERGI. : Defect Recognition and Image Processing in Semiconductors, In: Proceedings of the seventh conference on Defect Recognition and Image Processing, CRC Press, 1998.

[16] SUKKI, M.-EUN, K. K.-HOON, Y. C.: Abnormal Behavior of Midgap Electron Trap in HBGaAs during Thermal Annealing, Journal of Applied Physics 63 (1988), 4422, doi: $10.1063 / 1.340187$.

Received 14 June 2016

Arpád Kósa (Ing, PhD) born in 1987 is a young researcher at the Institute of Electronics and Photonics, Slovak University of Technology. He received his Ing degree in microelectronics from the Slovak University of Technology in 2013 and received the $\mathrm{PhD}$ degree in 2016. His research interests include semiconductor defect analysis and investigation by experimental and mathematical methods, electronics and microelectronics, and mathematical evaluation algorithm programming.

Miroslav Mikolášek (Ing, PhD) carried out his research in the area of microfluidic circuits at the Johannes Kepler University in Linz, Austria, and based on this work he received his Master degree in electronics from the Slovak University of Technology, Bratislava, in 2007. In 2011 he received his PhD degree in Electronics from the Slovak University of Technology. At present he works at the Institute of Electronics and Photonics, Slovak Technical University, in Bratislava. Main interests of his research include simulation and diagnostics in the field of amorphous silicon/crystalline silicon heterojunction solar cells.

Lubica Stuchlíková (Prof, Ing, PhD.) graduated from the Faculty of Electrical Engineering, Slovak University of Technology in Bratislava (STU) in 1990, received the PhD degree in 1996 and was appointed associate professor in 2006. She works as a teacher at the Institute of Electronics and Photonics. From 2016 as full professor. Since 1990 she has been interested in semiconductor defects engineering and electrical characterization of semiconductor structures, devices and materials.

Ladislav Harmatha (Assoc Prof, Ing, PhD) was born in Dobšiná, Slovakia, in 1948. He graduated from the Faculty of Electrical Engineering, STU Bratislava, in 1971, received the $\mathrm{PhD}$ degree in 1984 and was appointed associate professor in 1996. Since 1988 he has worked as a senior scientist in the field of semiconductor defects engineering. His research is focused on defects in semiconductor structures and their characterization by electrical methods (capacitance transient spectroscopy).

Beata Ściana (Ing, PhD) was born in Wroclaw, Poland, in 1965. She graduated in Electronics from the Wroclaw University of Technology, Faculty of Electronics, in 1990. From 1990 to 1993 she worked at the Elwro Electronics Factory in Wroclaw. Since 1993 she has worked at Wroclaw University of Technology and pursued researches in epitaxial growth (MOVPE method) and material characterization of AIIIBV semiconductor compounds for application in advanced microelectronic and optoelectronic devices. She received her $\mathrm{PhD}$ degree in Electronics from Wrocaw University of Technology in 2000 .

Wojciech Dawidowski (MSc, Eng) was born in Tomaszow Lubelski, Poland in 1987. He graduated from Wroclaw University of Technology, Faculty of Microsystem Electronics and Photonics in 2011. He is a PhD student and his research is focused on epitaxial growth of AIIIB V-N semiconductor compounds for solar cells, their fabrication and characterization.

Marek Tłaczała (Prof, Ing, PhD) graduated in electronics from the Faculty of Electronics, Wroclaw University of Technology in 1972. In 1973-1976 he worked at the Electrotechnical University in Leningrad (now Sankt Petersburg). He received his $\mathrm{PhD}$ degree in electronic engineering from the Electrotechnical University in Leningrad in 1976 and DSc degree from the Faculty of Microsystem Electronics and Photonics, Wroclaw University of Technology in 2002. Since 2009 he is full professor and head of the Semiconductor Devices Lab in the Faculty of Microsystem Electronics and Photonics, Wroclaw University of Technology. 